\title{
A 35-Year Comparison of Children Labelled as Gifted, Unlabelled as Gifted and Average-ability
}

Joan Freeman*

\section{Abstract}

Why are some children seen as gifted while others of identical ability are not? To find out why and what the consequences might be, in 1974 I began a study, in England, with 70 children labelled as gifted. Each one was matched for age, sex and socio-economic level with two comparison children in the same school class. The first comparison child had an identical gift, and the second taken at random. Investigation was by a battery of tests and deep questioning of pupils, teachers and parents in their schools and homes which went on for 35 years. A major significant difference was that those labelled gifted had significantly more emotional problems than either the unlabelled but identically gifted or the random controls. The vital aspects of success for the entire sample, whether gifted or not, have been hard work, emotional support and a positive personal outlook. But in general, the higher the individual's intelligence the better their chances in life.

Keywords: High Ability/Giftedness; Children; Comparative study.

\footnotetext{
* Professora Doutora pela Universidade de Middlesex, Londres, Reino Unido. Presidente fundadora do European Council for High Ability (ECHA).
} 


\section{Um estudo comparativo de 35 anos com crianças identificadas como superdotadas, não identificadas como superdotadas e com habilidades médias}

\section{Resumo}

Por que algumas crianças são consideradas superdotadas enquanto outras com habilidades idênticas não o são? Para descobrir por que e quais poderiam ser as consequências, em 1974, comecei um estudo, na Inglaterra, com 70 crianças identificadas como superdotadas. Cada uma delas foi agrupada por idade, gênero e nível socioeconômico com outras duas crianças da mesma turma escolar, para fins de comparação. A primeira criança possuía uma superdotação idêntica e a segunda foi escolhida aleatoriamente. A pesquisa foi desenvolvida por meio de uma bateria de testes e entrevista aprofundada de alunos, professores e pais em suas escolas e em suas residências e continuou durante 35 anos. Uma diferença significativa importante foi que aqueles identificados como superdotados tinham significativamente mais problemas emocionais que os que não tinham sido identificados, embora fossem identicamente superdotados, ou que os controles aleatórios. Os aspectos vitais de sucesso, em toda a amostra, dos que eram superdotados e os que não o eram, foram trabalho duro, apoio emocional e uma perspectiva pessoal positiva. Porém, em geral, quanto maior a inteligência individual, melhores eram suas chances na vida.

Palavras-chave: Altas Habilidades/Superdotação; Crianças; Estudo comparativo.

\section{Introduction}

Through the life-stories of the 210 individuals in the sample, my long study of gifted and non-gifted children, started in 1974, has shown that the only true difference between the gifted and everyone else is - their gifts. But how other people reacted to their specialness could make all the difference to the way the children developed into adulthood.

Being gifted as a child is very different from being gifted as an adult. Whatever obstacles the children had to overcome, these were small compared with what they had to accomplish as adults to be seen as highly achieving. Turning childhood prodigiousness into adult excellence is always the most difficult challenge. Life can be cruel and fate could turn a life upside down in an instant. The most sparkling potential sometimes had to be cast aside for the tiresome work of earning a living. How each person reacted could be seen as partly related to their intellectual ability to cope with distress, but more importantly to their personalities and views of life. I looked at each one's development set in the context of family life, itself a microcosm of the wider society they lived in (FREEMAN, 2000a). 
I use the word 'gifted' in its most frequent meaning of outstandingly high mental ability, and 'talented' to mean outstandingly high artistic ability, though the two do overlap and many in this study enjoyed both. I do not find that changing these adjectives makes any difference to that condition of exceptionality or to people's reaction to it.

I have found in my overviews of world provision for the gifted and talented, that formal definitions vary so widely in different cultures that no individual could fit them all (FREEMAN, RAFFAN and WARWICK, 2010: FREEMAN \& GEUNTHER, 2000; FREEMAN, 2008). For example, where Islam is strictly enforced, gifts are seen as the ability to memorise long tracts of the Koran - by boys - and argument is not encouraged. Yet elsewhere, curiosity is seen as positive. Again, in the Western world, 'gifted' children are usually those far in advance of their age-group, but in the Far East, notably Japan, giftedness is seen as the product of hard work and open to most children. Gender differences in recognised giftedness and the provision of opportunities to realise its potential vary greatly, even between Britain and the United States (FREEMAN, 2003).

Unfortunately, gifts which are vital to the smooth running of society such as entrepreneurship, economics or people-management are rarely considered by schools. Some gifted children can do almost anything brilliantly, whether sport, music or philosophy, while others are finely focussed on a single area, such as mathematics or music. Given the opportunity, I am certain that there is a much higher proportion of potentially gifted and talented individuals in the world than is currently recognised, individuals who would be capable of rising to extraordinary heights in many areas of endeavour.

\section{Longitudinal Studies of the Gifted}

The major benefit of longitudinal studies of gifted and talented children is tracking behaviour as it develops so that early indicators may be recognised and successful developmental procedures promoted for the benefit of others. Virtually all follow-up studies of gifted children are carried out on those selected by extremely high scores on IQ or other attainment tests; they demonstrate the kind of giftedness approved of by that society and at that time (FREEMAN, 2005).

Subotnik, Kassan, Summers \& Wasser (1993) have shown that giftedness may take many different forms; it may appear in quite unexpected situations and at different points during a lifetime. Those authors and I are in accord that it is not always possible to identify future gifts, which means that theories and educational programmes designed for children who are precocious in conventional school subjects may miss those whose gifts do not fit and who disappoint their teachers and parents with their school performances. Entrepreneurs are particularly notable as school drop-outs, such as the founder of the airline Virgin, Richard Branson, who left school at 15, Bill Gates, the founder of Microsoft who dropped out of university, as did Mark Zuckerberg, the inventor of Facebook. 
Attempting to avoid the trap of selecting children by school achievement, the Fullerton Longitudinal study in California began with 130 one-year-olds of unknown potential and their families, the only criterion being that they were healthy (GOTTFRIED, GOTTFRIED, BATHURST \& GUERIN, 1994). Regular measures of intellectual, physical and social development were taken from 1979 to 1997. Those with an IQ of 130 or more on the Wechsler Intelligence Test were deemed gifted and compared with the others. Early indications of giftedness were discovered and parents proved to be good judges. The researchers concluded that giftedness is a developmental phenomenon, which can rise - and fall - over time with the result that 'late bloomers' could be missed in a single testing.

However, population statistics do not provide entirely satisfactory controls for longitudinal studies because they are not specifically focussed on gifts and talents (FREEMAN, 1998). This was true, for example, in the Terman studies in California, which in 1925 selected 856 boy and 672 girl "geniuses" of IQ 130+, eventually producing more than 4000 variables (HOLAHAN \& SEARS, 1995), who describe how even for those days, there were considerable flaws in the sampling. In Chapter 2, 'The nature of the study', describe how "no private, parochial (religious) or Chinese schools" (P.11) were included. The subjects, aged between 2 and 22, were almost entirely the progeny of white university staff along with "occasional recruiting from his colleague's families" (p. 13), collected over a period of 7 years. Worst of all, as early as 1928 , a quarter of the original sample had simply been replaced. Further replacement continued for most of the years of research. Because of these constant changes in the sample, Terman's study was neither longitudinal nor valid. But it was, of course, interesting and seminal.

Terman's "geniuses" were considerably above-average in every way, including height and leadership qualities, probably because they enjoyed well above the population norms of nourishment, exercise and education. Yet reviewing that long work, Holahan \& Sears found that the (so-called) 'Termites' in their seventies and eighties were no more successful in adulthood than if they had been randomly selected from the same socio-economic backgrounds - regardless of their IQ scores. Louis Terman would have been disappointed. Indeed, this finding was mirrored in the findings of Subotnik, Kassan, Summers \& Wasser (1993) who investigated a sample of $210 \mathrm{New}$ York children selected for the Hunter College Elementary School by nomination and high-IQ scores (mean IQ 157). Not one had reached eminence by the ages of 40 to 50 , nor were they any more successful than their socio-economic and IQ peers in spite of their tailor-made gifted education.

The Seattle Longitudinal Study has been concerned with intelligence (though not focussed on giftedness) as well as ageing since 1956 (SCHAIE, 2005). It has examined expanding families over three generations. Although its sample size reached 6000 , it was constantly substituted with fresh people. It found that social effects influence the stability of IQ with increasing age. Intellectual and perceptual abilities remained high for the individuals who stayed active and open-minded: notably, people satisfied with their accomplishments in mid-life are at a considerable advantage 
as they age. The Munich Longitudinal Study of Giftedness began in 1985 with a sample of 26,000 children, identified on a wide variety of intellectual, personality and achievement tests (HELLER, PERLETH \& LIM, 2005). The team devised 30 identification scales, which disclosed a significant number of gifted under-achievers who were typically found to be more anxious, easily distracted and with lower self-esteem than the high achievers.

Many hard working and conscientious people offer gifted children special provision both in school and out-of-school. The great problem is measuring the longterm effects. To start with, achievement scores usually go up and they feel good about their experiences, but it does seem that the advantage of gifted education disappear over a few years (FREEMAN, 1998; BRADT, 2006). Without a long-term perspective, programmes for the gifted may not be justified. Who can say how much of the initial boost is due to the Hawthorne effect (attention and change) and whether the benefits will last over years?

\section{Measured Giftedness in the Long Term}

The measurement of intelligence is among the best and most resilient success stories in all scientific psychology, according to the American Psychological Association's task force (NEISSER, BOODOO, BOUCHARD, BOYKIN, BRODY \& CECI, 1996). After a century of solid, replicated research, the report concluded that intelligence levels are the preeminent measure to predict life outcomes in education and the workplace as well as aspects of health, such as how long people live. For example, a step-up of just one standard deviation in IQ in 11 year-old Scottish girls improved their chances of reaching the age of 76 by 25\% (WHALLEY \& DEARY, 2001).

Yet intelligence is only part of the complex dynamics of exceptionally high-level performance, which must include self-esteem, support and motivation - as well as opportunity (DWECK, 1999; FREEMAN, 2006). Biometric studies, involving families, twins and adoptees, provide reliable evidence of the environmental and genetic effects on developmental differences, both general and specific (e.g.: PLOMIN, DEFRIES, MCCLEARN \& MCGUFF, 2001). Work for more than ten years, at the John Hopkins University Center for Talented Youth (CTY), has found that even by the age of 12 , the participating students were significantly different from the general population on the personality test, the Myers Briggs Indicator (MILLS, 1993). However, none of them were randomly selected, all being volunteers for the out-of-school programmes (FREEMAN, 2002). The most consistent finding was that the gifted scored highly on intuition, as indeed is claimed for Nobel Prize winners (SHAVININA \& FERRARI 2004). Mills interpreted this as a preference for abstract and theoretical thinking, whereas most non-gifted students preferred to be factual and pragmatic.

Some follow-up studies are very small, which makes it difficult to draw reliable conclusions from them. For example, in Australia, for 20 years, Gross (2004) has followed up 10 boys and five girls originally aged 11 to 13 , chosen because their 
Stanford-Binet IQs were more than 160. In general, she saw the adolescents as having low self-esteem, "moderate to severe levels of depression", not to mention "loneliness, social isolation and bitter unhappiness" (p. 199), which Gross attributed to failures of provision in their education. As there were no controlled comparisons with any other children, it is difficult to tell whether the subjects were even representative of other Australian high-IQ children. The six American boy "prodigies" who were followed -up for 10-years (FELDMAN with GOLDSMITH, 1986) are a tiny sample. Even so, not one boy continued his advantage into adult achievement, a feature, the writers said, of 'hot-housed children'.

Child case-studies provide richness but can miss the wider environmental influences, particularly the different interactions of parents with siblings within a family, where each member reacts personally to expectations and encouragement.

\section{The Promotion of Gifts and Talents}

\section{Rising Intelligence}

It is of concern to longitudinal studies that the very idea of standardised intelligence measures may be changing in many cultures. A strange new phenomenon has been growing since about 1950, called the 'Flynn Effect' after Prof James Flynn of the University of Otago, New Zealand. The effect was named by Herrnstein and Murray, (1994) after the New Zealand political scientist James, R. Flynn, who did much to document it and promote awareness of its implications (FLYNN, 2007). Flynn has shown a year-on-year rise in measured intelligence, about three IQ points a decade. The increase has been highest at 20 points per generation (of 30 years), in Belgium, Holland and Israel, and lowest, at 10 points per generation, in Denmark and Sweden. Although the data are limited, it seems that the increase is accelerating. In Holland, for example, scores went up most (over 8 points) for the most recently measured period, 1972 to 1982 .

Yet while advanced countries may even be reaching a plateau by now, developing countries have yet to see this rise at all. Flynn believes it is due to modern changes - such as more intellectually demanding work, greater use of information technology and smaller families, so that each child gets more attention. For at least a century, first world youngsters have become very much better at manipulating abstract concepts such as hypotheses and categories. Something major is happening in their heads. It is not so much that natural intelligence is simply going up; the big changes are in the way it is used.

In theory, then, we should be seeing proportionately more gifted individuals as the years go by, and longitudinal studies should pick up the changes. The old reliable IQ test may no longer be the most appropriate to measure the development of the newer style of cognitive development. The old-style tests ask for much memorised information and is still the most popular, tying in with the school-style learning required for examinations. Yet certain intelligence tests which use abstract, non-verbal patterns, like the Raven's Progressive Matrices seem better able to cope with new-style 
intelligence. Flynn says it is not that our ancestors were more stupid, but that they thought differently.

This new style of cognition offers a greatly superior facility to be able to think through both theoretical and practical problems. Computers for education and even games can boost the curious child's knowledge and intellectual agility. Just using everyday appliances, such as VCRs, iPods, and mobile communications equipment, demands a more abstract type of perception and reasoning, which older generations can find extremely difficult. This change could even alter the bell-shaped curve which social scientists use to see what is normal and what is unusual. The gifted come in at the right-hand end in the slow downward curve, indicating relatively fewer of them. Possibly that part will not tail off so gradually from now on.

In my London practice for gifted children, I am seeing increasing numbers of unquestionably gifted children between two and five years-old measured within the top $1 \%$ of the measured population on the Stanford-Binet Intelligence Test. These tiny children appear to thoroughly enjoy the intellectual tasks, and it seems to me that the higher the intelligence, the greater the pleasure in the challenges. Items include drawing with a pencil, spotting similarities and differences in pictures, word games, lining-up geometrical shapes and spotting a missing bit of a picture. As I am the only psychologist in the UK doing this, I have no means of comparison, and it is difficult to know whether the increasing numbers of little gifted children is due to the Flynn Effect or to increased awareness among parents and teachers of gifts and talents needing special concern. The primary problem for their parents is one of education. Some can read fluently and do simple arithmetic even by two and a half years-old, long before they reach proper school at the age of five.

\section{Educational Provision for the Gifted and Talented}

Unfortunately, in no part of the world is hard scientific evidence over the long-term used as a basis for any educational action for the long-term benefit of gifts and talents. Typically, published research reflects that of the culture and language of the population on which it was done. In many published works, notably edited books (e.g. in Spain, France, Italy, Russia, and the USA) virtually every paper reflects that culture, without mention of the world outside, other than perhaps reference to North American big names. It is important, though, to know and compare the cultural approach taken in any educational promotion or study, because this 'grounds' the work in a specific epistemological stance - the belief system in which data are perceived and analysed and from which general conclusions are drawn.

I have never found a single scientific comparison between specific gifted programmes, either cross-culturally or within one country. There has been no objective testing of the longer term effects of summer schools or specialist courses with matched control groups, i.e., with groups not involved in any way in that particular provision. Nor can I find a comparison between one aspect of such a programme and any other, whether in school or out. As a result, it is hard to be precise as to what type of provision would be the most appropriate and effective in any given cultural situ- 
ation. International comparisons are generally made between competitions e.g. the Mathematics Olympiad. National advances and economic success can be surveyed and compared in terms of education, such as that by Lynn \& Vanhanen (2002) who identified a positive correlation between assessments of nation $\neg$ al mental ability and real gross domestic product in of 60 countries.

The Western model of diagnose-and-treat for educating the gifted and talented is in direct contrast to the Eastern model of open access for those who want to learn more, though both concepts operate across the world, often in the same place. Each reflects a social construction of identity and developmental potential. It is not always easy for educational practitioners to see the effects of unrecognised assumptions about gifts and talents, and it would not seem wise to copy any educational action directly from one culture to another without recognising and adapting to the inevitable differences in background and outlook.

\section{The Freeman Follow-up Study}

\section{Design of the Study}

In 1974, when I started this study, the widespread image of gifted and talented children was of rare exotic creatures. I believe that my work and that of others has changed the perception of the gifted and talented from the image of strangeness to that of being normal people with something special to offer the world. The methodology was designed to bridge statistical and in-depth approaches to provide a richer picture than either on its own.

Over three and half decades, the Freeman Follow-up Study has remained unique in two ways:

- It was set up with matched scientific comparisons from the start. Only through such a methodological design has it been possible to tap the origins of adult behaviour. If one only examines highly achieving individuals, there is no way of discovering how circumstances can affect high-level potential.

- The extensive in-depth face-to-face interviews were carried out in the children's normal environments and their teachers in the schools over very many years. As each of the children has negotiated growing up, this investigation has searched well below the surface of commonly used postal, telephone and even researcher-given questionnaires to reach levels of understanding that no other study of the gifted and talented has yet managed to achieve.

My initial concern was to find why some children were labelled as gifted while others - of identical measured ability and achievement - were not so described. The investigation used a battery of psychological tests (e.g. intelligence, personality, creativity and music ability) and in-depth interviews with the subjects, their parents and their teachers in their school and home environments. Perhaps inevitably over the decades, the research changed its nature, becoming less statistical and more personal, to examine the deeper socio-psychological effects of the individual's experiences in life as adults. 
To start with, though, the target experimental group ( $\mathrm{T}$ ) was 70 children aged between five and 14, described as gifted by their parents, almost entirely without testing, all of whom had joined the National Association for Gifted Children on behalf of their children (the UK association is made up mostly of parents). A search was then made across their 63 schools to find each one two comparison children matched for sex, age and socio-economic level, and sharing educational experience in the same school class.

The first comparison child was measured with the Raven's Matrices intelligence test as having an identical intelligence. That matching was within three raw score points in every case, rather than the less precise percentiles. Although each of these matched children had a virtually identical score to his or her target child, he or she had not been not labelled as gifted. Thus, the essential distinction between these groups was whether or not they had been labelled as gifted by their parents, who had demonstrated this by the simple criterion of joining the National Association for Gifted Children. The Second comparison child was taken at random from the class in respect of intelligence.

Ratings were made of the class teachers' reports on the children's school achievements (no uniform measure was available) and the head teachers' descriptions of school ethos and the population it drew on. Children and their parents were interviewed independently, each with their own piloted and specially designed open-ended questionnaire. The audio-taped transcriptions were rated, and together with other data (e.g. on home circumstances) produced 229 variables, which were statistically analysed with orthogonal comparisons and non-parametric analyses. The interview transcriptions were carefully scrutinised for further information which may not have been anticipated in the original ratings.

Of the whole sample, 170 children were at the 99th percentile of the Raven's Matrices. The Stanford-Binet IQ scores ranged from 46 children with less than IQ120 to 18 children above IQ160. 13 children hit the Stanford-Binet test ceiling of 170 IQ. Calculations to increase the IQ quotient were not considered to be either reliable or meaningful. Family finances ranged from very poor to very rich.

There has been attrition over the years, so that by 2010 , the sample had 80 subjects. Fortunately, the original groupings retained the same proportions, so that outcomes are systematic and recognisable.

\section{Some Findings from the Freeman Follow-up Study}

\section{The Label of Gifted}

As children, the labelled gifted were usually treated differently from the equally gifted but non-labelled children by their parents and teachers, whether positively or negatively. Most children did their best to comply with expectations. For example, a parent told me in front of their young son, that he was too clever to play with others of the same age, and not surprisingly, the boy indeed found it difficult to make friends. Pressures from school and parents could be strong. 
Some, as they grew up, felt they could never live up to others' expectations of their giftedness in terms of making their marks on the world and stayed in smaller and less demanding communities to become 'big fishes in small ponds' as Zeidner \& Schleyer (1999) have described. Typically, there was the woman of extremely high IQ who came from an educationally poor family. Her giftedness had become a major part of her self-identification, but it meant, unfortunately, that to have mixed with her intellectual peers at university would be too threatening. Instead, she chose a modest college in which she could shine unchallenged.

Some, though, chose to ignore their gifts to follow their low socio-economic status parents into low-level work. In spite of free educational opportunity and teacher encouragement, some never managed to fit comfortably into the cut and thrust of intellectually challenging work. As so many other researchers have found, it is not precocity, extremely high IQ scores, high marks in school, or grade-skipping which present the route to high adult achievements - except perhaps for those who continued in a similar path to become teachers at various levels.

\section{Emotional Development}

It was clear from the data that the labelled gifted had a far higher incidence of emotional problems when compared with the unlabelled but identically gifted at $(\mathrm{p}<1 \%)$. Although in each triad the labelled and unlabelled were in the same school class and so experienced identical teaching, parents of the labelled children made significantly more complaints about school provision. The long parental interviews in their own homes also disclosed that the labelled gifted children with emotional difficulties had significantly $(\mathrm{p}<1 \%)$ more difficult domestic circumstances, such as parental divorce or adverse experiences, which would disturb most children.

Not surprisingly, the home lives of the labelled gifted had an effect on their emotional development, as Cornell and Grossberg also found (1989). This was mirrored in the parents' and teacher's reports of the children's physical health. As children, the labelled gifted has significantly more physical as well as emotional problems, notably clumsiness and poor coordination, than the non-labelled children. Using both the Stamford-Binet IQ and the Raven's scores, along with the rated data from the interviewing, it was possible to see that it was not intelligence as such that caused these disturbances, but other matters in the children's lives. Yet, over and over again, the children's gifts were given the blame for any emotional problems.

Fortunately, as the children grew up and became more independent, most of these problems disappeared - though not all. My impression of the labelled group in their mid-forties is of more depression than in the other groups, but the sample is too small to analyse and I do not have the means of putting them all through a clinical diagnosis to verify this possibility.

I suggest that the common stereotype of the intellectually gifted as having more emotional problems, (e.g. poor emotional balance, lack of friendships, tantrums and abnormal emotional reactions) than the non-gifted is unjustifiable and 
dangerous. This is supported by much other research, e.g. Neihart (2002). The stereotype has three possible negative outcomes:

1. It raises teachers' and parents' expectations of emotional disturbance in children identified as gifted. Young children may adapt to this as a way of pleasing which becomes a way of life for them.

2. Subjectively, when identifying children as gifted, teachers and parents look for emotionally disturbed children and miss the non-disturbed.

3. Supposedly objective lists of characteristics for identifying the gifted often contain emotional problems.

In my study, how other people reacted to the gifted and talented made a big difference to the way the children coped with their special abilities and developed their sense of self to adulthood. A few of the gifted children were exploited for adult benefit, whether school or home, while for others, their feelings of worth were squashed for being 'too clever'. It could either take just a chance remark to affect a child's life, or the slow grind of parental pressure which could eat away at a child's self-confidence. Even very early experiences could affect the adult expression of high-level potential.

\section{Pressure}

Being gifted in a normal world means facing special challenges. I found, for example, that those who were accelerated in school (by up to three years) and who therefore had to cope with learning among classmates, who were older, bigger and more mature than they were, did not thrive emotionally or even intellectually, as well as they might have done. Teenagers, especially boys, were at a disadvantage because of their smaller size and parental restrictions, typically that they could not stay out as late as their older classmates. What's more, when they had left school, they found it difficult to be friends with the other older students.

Even in their thirties and forties, many who had been accelerated at school felt the loss of the ease and pleasure of friendships they did not have, as well as non-scholastic activities for which there was no time in the scramble to keep up with their academic work. Only 17 of the whole sample had been grade-skipped, as this is not a common practice in the UK. 16 of them, as adults, are determined that they would not allow this for their own children. Only one boy, who was tall and mature for his age, said it had been good for him, notably that he could leave school earlier. As one of the fathers said of his adolescent son who had been accelerated by two years in an all-male school, "I felt very sorry for him; he was still a boy and they were men".

A clear warning against too much academic pressure on high-IQ youngsters emerged from the research. Much of it came from schools aiming their pupils towards prestigious universities. Some youngsters seemed to subdue their personalities while striving for perfect grades, so that their healthy emotional development, including the freedom to play and be creative, was severely curtailed. Such pressure could have 
the opposite effect from what was intended when school-leavers' lives took unexpected turns. The worst affected were the accelerated boys specialising in science - eyes on microscopes - who missed out on social relationships. This limited the healthy development of their social skills and relationships, often resulting in poor self-images. Even in 2010, several men, still lonely in their single lives, told me spontaneously how they deeply regretted the loss of what they saw as a normal childhood.

Sometimes, far too much of the gifted young people's energy had gone into fighting their school regimes and their teachers, supposedly there to help them. Educational guidance for this sample was poor for the gifted, causing too many to dissipate their time and energies into wrong channels. At times, they told me that they had known exactly what they wanted to do, but were thwarted by reasons of school time-tables or teachers' opinions, and put their study energies into areas for which they were less well suited. One girl at a high-powered school, for example, was told firmly that biology was not for her. But her personality was strong enough to defy the school's advice. Secretly she entered a competition with her own biological research and won. Only then, did the school recognise her potential and permit her to study in the subject area of her choice. She is now a white-coated research pharmacist.

The social pressures which can diminish a growing youngster's feelings of worth were not much helped by the universities they attended. One of the unexpected outcomes of being gifted was that youngsters from modest homes could find themselves in highly prestigious universities and faced problems of snobbery. The social-class divide could be wide. At Oxford and Cambridge Universities, for example, nearly $50 \%$ of their intake is from (often very expensive) private schools. This sort of social challenge was greater for girls studying the arts: boys in the sciences were the least afflicted by such personal matters.

For example, Alison, a sensitive gifted girl from a poor home, made up of just herself and a single low-earning mother, won a prestigious place at Oxford University. Intellectually she was fine, but emotionally she could not cope with her fellow students, who were almost all from backgrounds with different outlooks. She was studying French, but had not been able even to afford one trip to the country, although many of her fellow-students had second homes there. Her only contacts were what the school provided - textbooks and lessons. She also had a very strong Liverpool accent (like the Beatles), which caused some laughter among her fellow students. Neither her school nor the university had in any way helped her to jump the social hurdle. Her feelings of self-worth were not strong enough. She left in tears before she had finished her first year to take a low level but emotionally secure job. Without some counselling help, especially for those whose home cannot provide it, the final link in a delicate situation can be lost, as it was in her case.

There are, of course, many non-scholastic routes to satisfaction in achievement, such as the woman of IQ 170, who when I first met her thirty years earlier was strikingly gifted in empathy. Throughout school, she acted as the class counsellor, the one to whom the others brought their troubles. She gained a psychology degree and further qualifications, and as an adult cares with love and deep satisfaction for the down-and-outs of her city, being neither well paid nor recognisably a high-flyer. 
The results of the pressure to gain high marks could be detrimental, especially if the parents had incorrectly labelled a child gifted, which could bring depression to the child. And teachers too could be at fault. Some at times seemed to feel a need to put the liveliest and more creative youngsters in their 'place' by being sarcastic or in one case, traumatically tearing up a boy's poem in front of the class because he had not stuck to the set subject. There could be an emotional price to play when parents and teachers placed unremitting pressure on youngsters to achieve brilliantly at all times. Even when they were small children, some told me explicitly how they felt they were not appreciated for themselves but were living out others peoples' dreams.

\section{Influences on Success in Life}

The most successful adults had been more robust and sociable as children, as seen in the group comparisons of the 1970s and 1980s. Werner \& Smith (1992) coined the term "resilient children" to describe successful survivors in very poor conditions, but I found that those same personality factors seemed to benefit the individuals in my sample, gifted or not. Signs of resilience in children from all kinds of backgrounds are that a child is 'engaging'. They would find supportive adults, responsive schools, sometimes sincerely felt religion and well above-average intelligence. In terms of conventional success in life, such as high examination marks, rising up the corporate ladder or making money, the primary building blocks were always keenness and hard work, allied with sufficient ability, formal educational opportunity and an emotionally supportive home. These factors are found over and over again.

High level creativity, as seen in adult careers, demands a particular type of personality which is relatively independent of other's opinions, and sometimes great courage in adulthood (ALENCAR \& FLEITH, 2003). The successful gifted architect who was a regular school truant, for example, did not do well in his exams and did not show his true talents until long after he left university with a modest degree. In 2010 he has his own highly successful architectural practice in central London.

Whether conventional and rule-abiding or enthusiastic for change, the children have usually carried their personal style through to adulthood. Maybe there were no tortured geniuses in this sample, because poor home circumstances, such as a constant change of 'uncles' did nothing but harm to the possibility of adult success. Having no money worries at home certainly helped, but not always. One very rich highly gifted girl had been strongly pressured academically. At school it had resulted in her anorexia nervosa, which she had controlled through her first degree at Harvard and then through Cambridge University for her higher degree. Suddenly, she cut loose, left for a less complicated part of the world, and returned with a husband who had little formal education. She is now the main financial support for her two children and her husband. She is happy. Such life paths are very difficult to put into number form.

Some outcomes were largely predictable and some certainly were not. I could never have imagined when I met the physically handicapped boy in his educationally and financially poor background that he would became a millionaire at the age of 34 . 


\section{Some Conclusions From this 35-Year Research}

In general (but not always), those with an exceptionally high IQs, say within the top $1 \%$, did much better in life even than those with merely a very high score, say within the top $10 \%$. The least successful had remained with less mature and effective, shorter-term cognitive techniques, like rote-memorising their lesson-notes at school, and rarely looking things up or using other resources. The most successful had found ways of organising their powerful mental abilities: they were more aware and made more efficient use of their personal learning styles. This not only helped them in examinations, but they could elaborate on their learning and take it creatively into adult life. Most high achievers in adulthood have enjoyed a mutually rewarding situation both at home and school, a feeling of comfort with their desire to learn, based on their parents' early pride and support as individuals. The less successful, even those with high IQs, had remained with less mature and less efficient, shorter-term techniques, like rote-memorising their lesson-notes.

\section{A Sense of Self}

The way circumstances affected the individuals was strongly influenced by their personalities and sense of self. Across the decades, I have seen many times how two people of the same high potential reacted to a similar obstacle in life. This could be, for example, getting a place at a prestigious university. Where one would see it as exciting and couldn't wait to get to grips with the challenge, another would take fright and give up.

Having tested and taken careful notes on their personalities from the beginning, I found that whether youngsters were modest, conventional and rule-abiding, or constantly straining to change the world, their personal style was recognisable in adulthood. Their individual differences were remarkably lasting. Life can throw terrible problems to youngsters, who will react according to their abilities and personalities. Poor emotional home circumstances, such as a constant change of 'uncles' in their mother's bed, financial insecurity and fighting parents, did nothing but harm to the possibility of the children's adult excellence (FREEMAN, 2000a).

A school, particularly the respect of teachers, is important to the developing young person. They set the outlook of youngsters for what is to come. School influences have been found to be more influential in the long-term than university or college. Some gifts were more encouraged in schools than others, particularly science and mathematics, possibly because easily recognisable outstanding results could be more readily achieved in those subjects.

\section{Growing Up}

Being gifted as a child is very different from being gifted as an adult. Whatever obstacles the children had to overcome, these were small compared with what they had to accomplish as adults to be recognised as gifted achievers in the world. For every one of these gifted children, turning their childhood prodigiousness into adult excellence was always the most difficult challenge of all. Life could be cruel or simply 
boring. Sometimes fate turned a life upside down, and sometimes gifts had to be pushed aside for the tiresome work of earning a living. High-level creativity, as seen in adult careers, demanded strength of personality to act independently, sometimes noticeable in childhood.

This longitudinal research benefitted greatly from recording the growing up of gifted and talented as events and their outcomes happened, rather than being imperfectly remembered years later. The police are very familiar with sincere distortions of memory, but psychologists seem more innocent in retrospective research. The way children develop is neither smooth nor can their progress be reliably predicted from research snap-shots in childhood or the teenage years. Some children emerge from poor prospects to become successful adults, while others may never see their gifts and talents realised.

I am certain that investigating children without detailed reference to the psychological circumstances of their daily lives is like examining a fish out of water - the influencing environment is missing.

\section{Freeman's Sports Approach}

To support the development of gifted potential most effectively throughout life, it is important to follow indicators such as personal interests. The problem with using precocity, as the prime identifying feature of gifts and talents could be responsible for its later apparent loss often called 'burn out'. This may be due to age-peers catching up or the gifted losing interest in the area of their exceptionality. It was clear from this research that the children of high ability who were successful in school and in later life not only had access to enough opportunity, but had received the emotional support they needed to take advantage of it.

Drawing on my own and others' work, I propose the following system of keeping the door to opportunity open for all, giving gifts and talents the chance to develop in thier own manner and time (CUPERTINO, 1996; FREEMAN, 2000b). Freeman's Sports Approach is based on the model of how sport is provided in schools. It is a way of helping children of high potential who may not be showing their gifts and talents at the time. It works on identification by provision, in the same way that sport is normally provided for all who want it. The Sports Approach provides a 'smart context for learning'. It advocates that given the opportunity and with guidance, the highly able and motivated (features recognised as essential for building excellence) should be able to select themselves to work at any subject at a more advanced and broader level.

This does not necessarily mean grade-skipping, but in the same way as those who are talented and motivated in sport can select themselves for extra teaching/ coaching and practice and aim to be their best, they could opt for, e.g. extra foreign languages or physics. Of course, such facilities must be available to all - as sport is - rather than only to those pre-selected by tests, experts or money. It is an inclusive formula. This is neither an expensive route, nor does it risk emotional distress to the children by removing them from the company of their friends and age-peers. 
It makes use of research-based understanding of high ability, notably the benefit of focusing on a defined area of the pupil's interest, as well as providing each youngster with what they need to learn with.

To practice the Sports Approach, teachers need training in differentiated teaching methods, in addition to a variety of specific techniques for bringing out high -level potential, such as helping pupils to collect information for a portfolio. Most importantly, education authorities should coordinate and share the approach and facilities. Recognition of gifts and talent in this way would also include recognition of the provision to which the students had access. This could be done by a rating scale so that children who were excelling within their context would be seen to be doing so and not penalised because they had poorer provision than others to teaching and material to learn with. An overview of the Approach is presented below.

\begin{tabular}{|l|}
\hline Freeman's Sports Approach \\
\hline - Identification should be process-based and continuous \\
\hline - Identification should be by multiple criteria, including provision for learning and \\
outcome \\
\hline - Indicators should be validated for each course of action and provision \\
\hline - The pupil's abilities should be presented as a profile, rather than a single figure \\
\hline $\begin{array}{l}\text { - Increasingly more focussed criteria should be employed at subsequent learning } \\
\text { stages }\end{array}$ \\
\hline $\begin{array}{l}\text { - Recognition should be given to attitudes possibly affected by outside influences } \\
\text { such as culture and gender }\end{array}$ \\
\hline $\begin{array}{l}\text { - The pupils must be involved in educational decision-making, notably in areas of } \\
\text { their own interest }\end{array}$ \\
\hline
\end{tabular}

\section{Postscript}

After innumerable hours of interaction and investigation with the individuals in this sample, and their teachers and parents, I had to conclude that many influences on happiness and success are like love - it is possible to say how it feels and what happens because of it, but there is no sure recipe to apply to others. For the rest, we do have very clear information about what the gifted and talented need by way of support towards self-fulfilment- an education to suit their potential, opportunities to flourish and people who believe in them. For greater understanding of both the methodology and outcomes of this study, I have selected 20 of the most gifted who epitomise different aspects of this exceptionality and in 2010 published their detailed life-stories in the acclaimed book - Gifted Lives: What happens when gifted children grow up.

\section{References}

ALENCAR, E. M. L. S. de \& FLEITH, D. de S. 'Contribuiçóes teóricas recentes ao estudo da criatividade/ Recent theoretical contributions to the study of creativity'. Psicologia: Teoria e Pesquisa, 2003, v. 9(1), p.1-8. 
BRADT, S. High school AP courses do not predict college success in science. Harvard University Gazette, 2003. Disponível em: <http://www.news.harvard.edu/gazette/2006/02.23/05-ap.html>. Acesso em 28 de abril de 2013.

CORNELL, D. G. \& GROSSBERG, I.N. Parent use of the term "gifted": Correlates with family environment and child adjustment, Journal for the Education of the Gifted, 1989, v.12(3), p. 218-230.

CUPERTINO, C. Collaborating to meet the needs of the gifted in Brazil. Theory into Practice, 1996, v. 35, p. 220-224.

DWECK, C.S. Self Theories, their Role in Motivation, Personality and Development. Philadelphia: Psychology Press, 1999.

FELDMAN, D.H. \& GOLDSMITH, L.T. Nature's Gambit: Child Prodigies and the Development of Human Potential. New York: Basic Books, 1986.

FLYNN, J.R. What is Intelligence? Cambridge: Cambridge University Press, 2007.

FREEMAN, J. Educating the Very Able: Current International Research. London: The Stationery Office, 1998.

FREEMAN, J. Families, the essential context for gifts and talents, In: HELLER, K. A. et al, International Handbook of Research and Development of Giftedness and Talent. Oxford: Pergamon Press, 2000, p. 669-683.

FREEMAN, J. Teaching for talent: lessons from the research. In: LIESHOUT, C. F. M. van \& HEYMANS, P. G. (Eds.) Developing Talent across the Lifespan. London: Psychology Press, 2000, p. 231-248.

FREEMAN, J. Out of School Educational Provision for the Gifted and Talented around the World. Report for the Department for Education and Skills (UK Government), 2002. Disponível em: <http://www.joanfreeman.com>. Acesso em 28 de abril de 2013.

FREEMAN, J. Gender differences in gifted achievement in Britain and the USA. Gifted Child Quarterly, 2003, v. 47, p. 202-211.

FREEMAN, J. Permission to be gifted: how conceptions of giftedness can change lives. In: STERNBERG, R. \& DAVIDSON, J. Conceptions of Giftedness. Cambridge: Cambridge University Press, 2005, p. 80-97.

FREEMAN, J. The emotional development of gifted and talented children. Gifted and Talented International, 2006, v. 21 , p. 20-28.

FREEMAN, J. Gifted Lives: What happens when gifted children grow up. London: Routledge/Psychology Press, 2010

FREEMAN, J. \& GUENTHER, Z. C. Educando os Mais Capazes: Idéias e Ações Comprovadas. São Paulo: Editora Pedagógica e Universitária (EPU), 2000.

FREEMAN, J., RAFFAN, J. \& WARWICK, I. Worldwide Provision to Develop Gifts and Talents. Reading: CfBT, 2010

GOTTFRIED, A.W., et al. Gifted IQ: Early Developmental Aspects. New York: Plenum, 1994.

GROSS, M.U. M. Exceptionally Gifted Children. London: RoutledgeFalmer, 2004.

HELlER, K. A.; PERLETH, C. \& LIM, T. K. The Munich model of giftedness designed to identify and promote gifted students. In: STERNBERG, R. J. \& DAVIDSON, J. E.(Eds.) Conceptions of Giftedness. London: Cambridge University Press, 2005. p. 147-170.

HERRNSTEIN, R. J. \& MURRAY, C. The Bell Curve: Intelligence and Class Structure in American Life. New York: Free Press, 1994.

HOLAHAN, C. K. \& SEARS, R. R. The Gifted Group in Later Maturity. Stanford, CA: Stanford University Press, 1995.

LYNN, R. \& VANHANEN, T. IQ and the Wealth of Nations. London: Greenwood Press, 2002.

MILLS, C. J. Personality, learning style and cognitive style profiles of mathematically talented students. European Journal for High Ability, 1993, v. 4, p. 70-85.

NEIHART, M, et al. The Social and Emotional Development of Gifted Children: What Do We Know? Washington: Prufrock Press, 2002.

NEISSER, U., et al. Intelligence: Knowns and unknowns. American Psychologist, 1996, v. 51, p. 77-101. 
PLOMIN, R., et al. Behavioral Genetics. New York: W H. Freeman, 2001.

SCHAIE, K. W. Developmental influences on adult intelligence: The Seattle Longitudinal Study. New York: Oxford University Press, 2005.

SHAVININA, L. V. \& FERRARI, M. (Eds.) Beyond Knowledge: Extracognitive Aspects of Developing High Ability. Mahwah, New Jersey: Erlbaum, 2004.

SUBOTNIK, R, et al. Genius Revisited: High IQ Children Grow Up. New Jersey: Ablex, 1993.

WERNER, E. \& SMITH, R. Overcoming the Odds: High Risk Children from Birth to Adulthood. Cornell: Cornell University Press, 1992.

WHALLEY, L.J. \& DEARY, I.J. Longitudinal cohort study of childhood IQ and survival up to age 76. British Medical Journal, 2001, v. 32(2), p. 1-5.

ZEIDNER, M. \& SCHLEYER, E. The big-fish-little-pond effect for academic self-concept, test anxiety, and school grades in gifted children. Contemporary Educational Psychology, 1999, v. 24, p. 305-329.

\section{Correspondência}

Joan Freeman - 21 Montagu Square, London W1H 2LF - London, United Kingdom.

E-mail: joan@joanfreeman.com

Recebido em 12 de março de 2014

Aprovado em 06 de junho de 2014 